\title{
O Renascimento Pessoal e Técnicos de Antigos Formandos em Clowns Numa Oficna de Rito de Iniciação
}

\author{
Santos, Adrielle Mayara Leite dos; Carvalhar, Amanda K. da Silva; Mattos, Ana \\ Luiza Schetino; Uchoa, Caroline Louise Mesquita \\ Universidade Federal de Pernambuco — adriellemlsantos@gmail.com
}

Introdução: o processo de formação em palhaço tem como ponto de partida o ritual de iniciação, o qual é um processo de pesquisa aberto capaz de favorecer a possibilidade de novas criações e mudanças. a partir dessa perspectiva, participantes, os quais são estudantes de saúde, já formados na oficina de clown, decidiram retomar seu contato com a técnica ensinada no ritual de iniciação. Objetivos: Almejou-se, desse modo, desenvolver o aprimoramento técnico anteriormente adquirido após a participação da oficina de rito de passagem de iniciação de novos palhaços. Metodologia: para que isso fosse possível, antigos formados desse ritual de iniciação participaram da oficina dirigida por um instrutor (monsieur), na função de monitores, com a finalidade de auxiliar os novos formandos. a oficina teve duração de 48 horas, divididas em 12 encontros e agrupados nos módulos de jogos, físico e estético. Os módulos de jogos trabalhavam a confiança dos participantes em si mesmo e nos companheiros, enquanto o módulo físico e estético promoviam uma nova percepção do corpo e dos sentidos. Além disso, em todos os módulos ocorriam pequenas tutorias sobre a história e a figura do palhaço. Resultados: Após cada encontro, observouse, no discurso de todos os monitores e do relato de seus respectivos diários de bordo, que as ferramentas técnicas exploradas foram de grande valia para contribuir não apenas com o fortalecimento da técnica de seus respectivos clowns, mas, sobretudo, com a humanidade de cada um. Conclusão: o processo de formação em palhaço nunca está finalizado, pois a aplicação de sua técnica também está relacionada a questões do homem que estão em constantes transformações. Desse modo, o desenvolvimento de um clown impera pelo refinamento de sua sensibilidade e aceitação de sua pequenez como ser humano, pois não se pode acreditar num palhaço que não reconhece esses sentimentos em si mesmo.

Santos, Adrielle Mayara Leite dos; Carvalhar, Amanda K. da Silva; Mattos, Ana Luiza Schetino; Uchoa, Caroline Louise Mesquita. O Renascimento Pessoal e Técnicos de Antigos Formandos em Clowns Numa Oficna de Rito de Iniciação. In: Anais do Congresso Internacional de Humanidades \& Humanização em Saúde [= Blucher Medical Proceedings, num.2, vol.1]. São Paulo: Editora Blucher, 2014. ISSN 2357-7282 DOI 10.5151/medpro-cihhs-10356 